DOI: $10.15503 /$ jecs20162.158.179

\title{
THROUGH THE (NOT SO) PINK GLASSES: GENDER BIAS IN INTIMATE RELATIONSHIPS
}

\author{
MONIKA GROCHALSKA \\ Faculty of Social Science, \\ University of Warmia and Mazury in Olsztyn, \\ Żołnierska Str. 14, 10-561 Olsztyn, Poland \\ E-mail address: monika.grochalska@uwm.edu.pl
}

\begin{abstract}
This article was written as part of the project funded by the National Science Centre allocated on the basis of the decision no DEC-2011/01/D/HS6/02470. It shows how social representations of intimate relationships are shared among women and where they are rooted. According to Serge Moscovici, social representations are systems of values, ideas and practices, which allow people in groups to understand each other. Thus women have such a system, which is created through their entire life within the process of informal learning. During this processes some gender bias is imposed. This bias becomes a part of social representations of intimate relationships and influences practices of "being-in-relationship". Those practices often do not fit life situations, contributing to the deterioration of women's quality of life. All these processes are analysed on the basis of data taken from focus group interviews (FGI) with women. During interviews women often referred to some shared meanings, which constitute their social representations. Finally, these interviews show, that close relationships are highly affected by gender bias, thus they are full of misunderstandings and internal conflicts. The findings highlight the role played by the social representations in women's subjective experience of their intimate relationships.
\end{abstract}

Key words: gender, informal learning, family, social representations, bias, adult learning, experience, intimate relationships

\section{INTRODUCTION -INTIMACY AND WOMEN'S QUALITY OF LIFE}

Intimacy is a very important aspect of our lives. Intimate relationships determine the quality of life. In terms of importance to the overall well-being, marriage is the second factor, just after age (Czapiński, Panek, 2015, p. 194). In recent research concerning quality of life, moderately negative predictors of psychological well-being are: (a) having dependent children and (b) being a woman (Czapiński, Panek, 2015, p. 434). Women in Poland can feel quite unhappy with their lives, because of pretty bad relationships. Their partners 
do not fit their high social expectations. For women who experience themselves as having problems in relationships, current social representations of "ideal relationship" and "ideal partner" can induce feelings of failure or being/having an inadequate partner.

"The pink glasses" in the title of this article is ambiguous. It suggests that we should take a gender oriented view on representations of intimate relationships which are created within the socialization process. But the sight we get, against this popular saying, is rather far from being optimistic. Social representations are piles of knowledge about people, things, situations, relations, created on the basis of our experiences. They are anchored in patriarchal tradition, thus full of gender bias. It seems interesting to take a closer look at gender bias as a basis of social representations constituting intimate relationships. This implies understanding of key forces that shape and are shaped by women's social representations.

\section{SOCIAL REPRESENTATION - WHAT IS THIS? DEFINITIONS}

In a literature one can find a lot of differing definitions of the term "social representations". First the author, who is considered the father of this concept, is Serge Moscovici. In the words of S. Moscovici (2000), social representations correspond to the symbolic substance, which enters into their elaboration and to practice, which produces this substance. We should perceive the representations exactly as we see the real objects.

Individuals and groups are not only passive receptors. They think for themselves, produce and communicate their own specific representations and solutions to questions they pose themselves. Everywhere people analyse, comment, concoct their unofficial "philosophies" which have an impact on their social relations, choices, the way they bring up the children and make plans for the future. Events, sciences, ideologies only provide them with "food for thought" (Moscovici, 2000, p. 30). Representations have their inner structure and dynamics. Concluding S. Moscovici's theory, social representations are systems of values, ideas and practices with double function of enabling orientation and communication.

Another important researcher of social representations is Gerard Duveen. The leitmotif of G. Duveen's work has been the process through which children assimilate the beliefs of their communities and thus acquire their social identity, which in turn enables them to become social actors. When dealing with the ontogenesis of social representations, G. Duveen has emphasized their interconnection with individual activities (Castorina, 2010, p. 18.1). "In the course of constructing an identity children draw upon the social representations available to them and in doing so also locate themselves in a particular position within this collective system of meaning. For the young child meanings are more clearly established through their practical activity than 
their intellectual understanding" (Duveen, 1993, p. 2). In the course of the social gender identities development children adopt positions which are more or less clearly marked within the social representations of gender. There is a possibility that the same representation gives rise to different social identities (Duveen, 1993, pp. 3-4). Moreover the teachers and parents have representations of how children develop, which are also linked to gender. Different expectations arise of the how girls and boys will develop. This dynamic points the children along the path of a gender career (Duveen, 1993, p. 4).

The next author who works with G. Duveen on social representations - Denise Jodelet (1991), claims they are images that condense manifold meanings that allow people to interpret what is happening; categories which serve to classify circumstances, phenomena and individuals with whom we deal, theories which permit us to establish facts about them. When we consider social representations embedded in the concrete reality of our social life, they are all the above together.

Social re-presentation, as a socio-cognitive practice (Jodelet, 1998; Moscovici, 1998), is something we do in order to understand the world in which we live and, in doing so, we convert these social representations into a particular social reality, for others and for ourselves (Philogéne, Deaux, 2001). Such an approach one can find in the comprehensive review of Gina Philogéne and Kay Deaux - two researchers interested in explaining how humans construct a framework of shared references which imposes a way of thinking about the world.

In learning about the world in which we live, we take on particular 'presentations' of that world and re-interpret them to fit with what we know 'already'. We take on 'presentations' and re-present them. In this process the social representation may be confirmed or perhaps re-articulated or re-enacted in various ways. Social representations, therefore, come to constitute our realities (Foster, 2003; Moscovici, 2000). Social re-presentation gives us a way of making sense of and so constituting socially significant phenomena. For example, for Juliet Foster mental illness is such phenomenon with its central aspects of unpredictability, permanence, violence and otherness.

Many other studies within social representations have highlighted re-presentation as a practice. For this reason, many social representations researchers use a methodology that enables them to actually witness or even experience the social representations operating in particular contexts or encounters (Howarth, 2006, p. 16).

The term "cognitive polyphasia" implies that different and potentially incompatible systems of knowledge can co-exist within one social group and can be employed by one and the same individual. In this context, social representations are created and transformed through processes of anchoring and objectification. Anchoring is a process of classification which locates something foreign within the familiar. Objectification is a process of externalization by which representations are projected into the world (Moscovici, 1998). 
According to Caroline Howarth, different representations relate to, defend or challenge different social identities (Howarth, 2002). They are institutionalized in social and cultural practices (Jovchelovitch, 2007). They also support (unequal) social relations and sustain public discourse. At the same time representations are contested and transformed (Duveen, 2001).

\section{THE SOCIOGENESIS OF SOCIAL REPRESENTATIONS}

Social representation is both a communication process in social groups and the result of this process. Social representations are socially developed and collectively shared. They result from a process of communication and discourse, so they are shaped in discursive processes. It makes them useful to analyse how discourses influence social representations and indirectly also a social practice (Höijer, 2011, p. 6). Discourse and communication with their formative potential exist within "reflexive" groups. The members of a reflexive group collectively elaborate the rules, justifications and reasons for beliefs and behaviour within their group-relevant daily practice. Social representations are the result of these processes. Mass-media communication and conversations between people provide them with elements of new knowledge, image and metaphors. They do not have to be "true", but are "good to think". That is how "individual" thinking turns into a social practice (Wagner, 1994, p. 208).

Social representations are not shared with idiosyncratic and private knowledge. Social representation as a process takes place only in groups and societies in which social discourse includes communication of shared and divergent points of view on many topics. But re-transformations and changing conceptions of social objects can only occur as a result of changes in life conditions in a society. Collective thinking and reflexivity are necessary conditions to develop social identity. Social identity is knowing to which group one belongs and this group defines common background knowledge, common sense and justificatory patterns. This knowledge allows members of the group to place themselves within a common discursive space. It enables communication. Discursive processes have to extend potentially across all members of a group, who are producers as well as recipients of common-sense knowledge. Results of collective working out of knowledge should be also accessible to all members of the group. This collective wisdom has two functions: it is base for communication and the core of social identity, only if it is public for all members of the group. Discourse can change social practice and social representation itself (Linton, 2015, pp. 31-35).

In this particular case - social representations of feminine and masculine roles and intimate relationships are a basis of women's communication and a core of their social identity. Changing discourses of femininity and masculinity change these concepts themselves and social practice of "being-in-relationship". Categories of femininity and masculinity are dichotomous and 
complementary like others such as "health" vs. "illness", "peace" vs. "conflict". But it is worth noticing that such categories usually work as contrasting the "a-normal" with the "normal". In patriarchal society we can assume that femininity can be perceived as the "a-normal" category.

The rationality of social representations lies in the relation between the represented knowledge and the available evidence. They do not necessarily correspond to external reality.

A very important term is "holomorphy", which means meta-information about the reference group contained in social representations. "Holomorphy" refers to relevant aspects of a social group visible in an individually represented, but shared knowledge system. Meta-knowledge is needed by people to differentiate between representational and singular opinions. Moreover people are usually able to attribute representations to their in group or to an out group. Reflexivity involves knowing what my group knows and having an idea of other groups' knowledge systems. In the course of social conflict so called "polemic representations" are generated. They are mutually exclusive, characteristic for different subdivisions of a society. They are usually the cause of antagonistic relationships between groups. Thanks to their social representations group members know what is a set of correct actions in a given situation. They also know what behaviour or actions can be expected from their co-actors in a social environment. Interactions can be reasonable rather than uncoordinated only because of described mechanism (Wagner, 1994, pp. 209-211).

Private knowledge stands in opposition to social knowledge. One can find in this category any kind of idiosyncratic knowledge, personal attitudes, subjective theories and individual cognitive representations. In a private knowledge system it is necessary to define and categorize individually relevant situations, as well as to explain subjective experience and stabilize its holder's self-esteem. This system is free from opinions of other people and from any kind of reflexive group, where its content would be accepted as a social representation. Knowledge can be considered social, when these ideas coordinate a reflexive group's practice (Moscovici, 2000, pp. 36-41).

There are five attributes characterizing social representations (Wagner, 1994, pp. 212-214): 1) theory-like structure with a core and a set of peripheral elements, 2) metaphorical form of figurative schema, 3) objectification, 4) ability of anchoring new experiences, 5) being collectively shared.

It is possible to discriminate different types of social representations and distinguish inter-subjective social representations from subjective knowledge (Wachelke, 2012, p. 65). Thus below mentioned criteria are needed (Wagner, 1994, pp. 213-216):

1 - functional consensus - necessary to maintain the group as a reflexive social unit, standardize the self-system, the self-categorisation processes and the interactions of a qualified majority of group members;

2 - criterion of relevance - social representations refer to socially relevant objects or affairs; they are relevant, if the behaviour pattern of individuals 
or groups changes in the presence of such an object;

3 - criterion of practice -one can speak of a new social representation when thinking and behaviour of a majority of group members have changed as a consequence of its creation;

4 - criteria of holomorphy-each individual holding such a representation has also the idea of the "normal" behaviour of potential partners in a situation evoking a specific representation, moreover individuals, in general, know which representation can be expected to be shared and with who (which reference group);

5 - criterion of affiliation - there has to be some group or subculture within which the knowledge is part of common sense.

According to Wolfgang Wagner (1994, p. 216), there are three fundamental fields of social representation research: a) folk-science; b) hegemonic and emancipated representations of cultural and social objects; c) polemic representations of social and political structure and events.

The following diagram illustrates the process of social representations socio-genesis. It shows a great role of discourses in the process of creating new social representations.

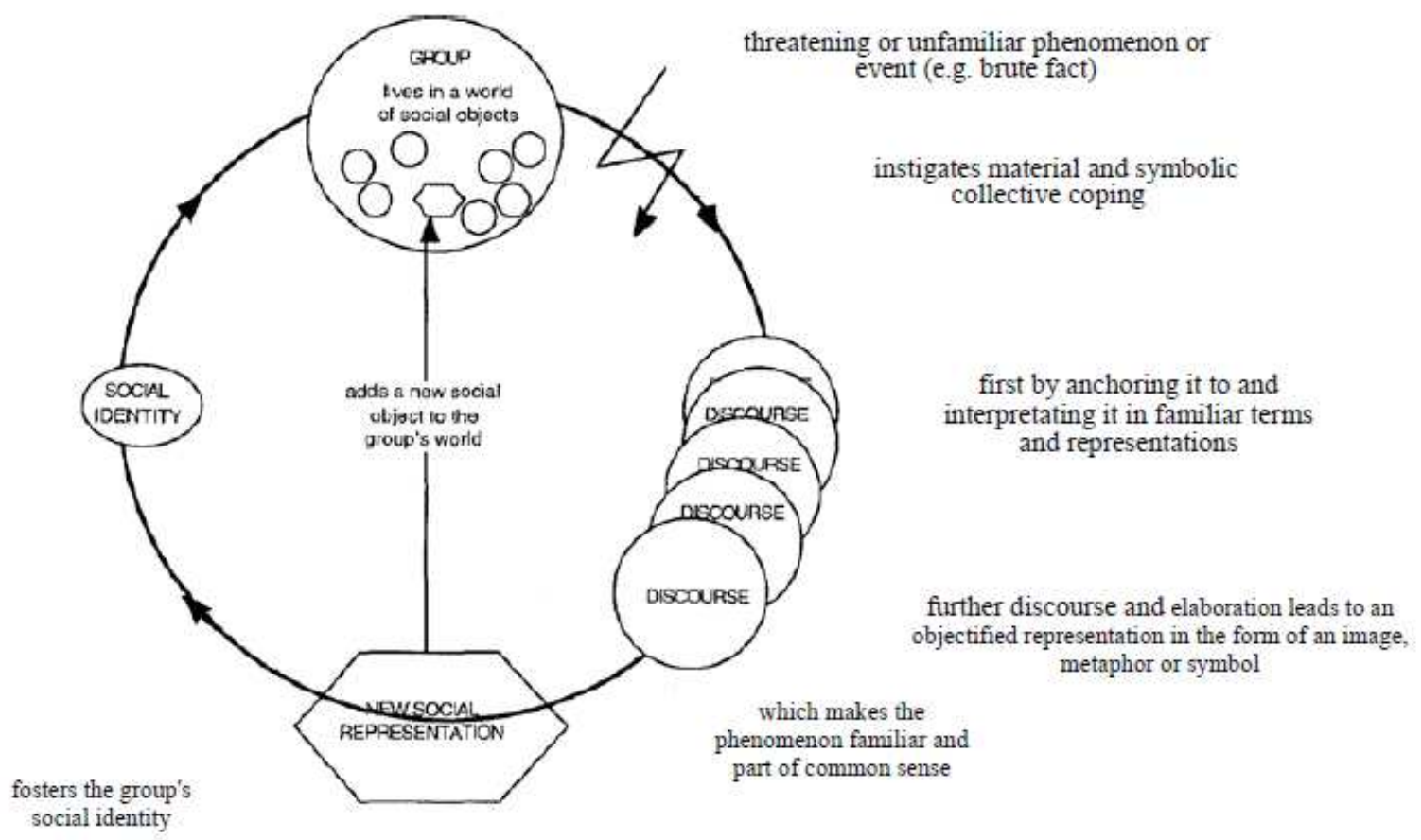

Fig. 1. The sociogenesis of social representations.

Source: Wagner, Farr, Jovchelovitch,, Lorenzi-Cioldi, Marková, Duveen, Rose (1999).

A very important phase of this process is a symbolic coping, which involves "anchoring" - to understand the unfamiliar phenomenon the group has to name it and interpret in familiar terms and representations (Wagner, 1994, pp. 205-206). 


\section{SOCIAL REPRESENTATIONS OF GENDER}

G. Duveen (2000) uses the term "social representations of gender". These are structures that reproduce gendered identities and gendered relations. This serves to maintain and defend gendered differences in the social order.

As G. Duveen's research indicates, children are born into a world which is already structured by the representations circulating in the communities. They grow up to become participants in these communities, so they have to take on some of those representations. Gender is central among the representations which structure children's lives. It is one of the earliest social categorisations (Duveen, Shields, 1985) and it provides one of the first forms of social identity which children acquire. A gender identity is first extended to the child even before birth, then as a new-born infant and only subsequently the meaning of this social act of categorisation is internalised by the child (Wagner, Farr, Jovchelovitch, Lorenzi-Cioldi, Marková, Duveen, Rose, 1999, p.6).

The sex of the new-born is among the first things adults are aware of. From the very beginning they start to think of and treat the child as either "a boy" or "a girl". Socially constructed gender representations tell adults all they need to know about how a child should be and why (Glaveanu, 2009, p. 2.6).

Despite great uproar around changes connected to gender roles, men still hold the majority of social positions providing high incomes, power and prestige. And they still shirk the major part of housework, even if their female partners work. The main "guilty" of this situation is socialization process. Beliefs, norms and values defining femininity and masculinity are instilled within this process. Those forces are very subtle, even socially "invisible", but their consequences are very significant (Turner, 1998, p. 128). Women's life choices concerning their work, career pathways and having children seem to be their individual, free decisions, while usually they are dictated by structural factors. Of course subjective predispositions, attitudes and motivation are also important, but factors such as social policy, stereotypes, whole social context modify and restrict a set of possibilities taken into account (Crompton, Lyonette, 2005, p. 616).

Parental practices differ because of their children's gender. Both mothers as well as fathers have different expectations from boys and from girls. Girls are prepared for traditional female roles - mainly daily chores, like cleaning up, cooking, taking care of children, but also to submission and subjection to a man. Parents connect girl's future to roles of a mother and a wife. Girls often do not feel as safe as boys. They rarely depart from home and they need less space to play than boys. Later on, when they are adults, they also take less physical space and they behave quieter (Kaschak, 2001, pp. 129-130). A similar effect on girls has the hidden curriculum at school (Lisowski, 1996, pp. 85-86). Whereas in the case of boys, parents more often expect them to achieve high social positions and they bring up their sons to 
this kind of future. Parents approve boys' dominant behaviour, sometimes even aggression, they teach them how to hide emotions (e.g. saying that "boys don't cry”) and to show courage („behave like a real man”). Such examples are always in contrast to characteristics and behaviour of girls (Nowak-Dziemianowicz, 2002, pp. 139 - 163). In early childhood boys are often encouraged to examine their environment. This makes them more willing to fill the streets and labour market in their adult lives (Kaschak, 2001, p. 129).

It is still quite common to think that gender is only a reflection of natural (biological, hormonal, chromosomal) differences between sexes. Whereas the feminist movement of the 70's and 80's showed us a completely different perspective - masculinity as well as femininity, their definitions, gender divisions, structures of masculine domination and eventually the concept of gender itself are entirely socio-cultural constructs (Thorne, 1993, p. 2).

There exist many different theories concerning the ways of learning gender: psychoanalytic theories, social learning theories, cognitive development theories and Gender Schema Theory of S.L. Bem (Renzetti, Curran, 2005, pp. 103-118; Dakowicz, 2000, pp. 20-23; Chylewska-Barakat, 2002, pp. 53-57). However in this context more reasonable is analysis of the process of becoming a man or woman with its social determinants then theories themselves.

Children are socialized according to "gender rules" existing in society. Socialisation influence, perfectly imaged by (stereo)typical clothes and toys on the covers of parents' magazines, have many sources. Parents dress their babies - girls in pink and boys in blue clothes, they give female or male names, toys, and even arrange babies' bedrooms in accordance with their gender. They also expect different behaviour.

Then during the school years teachers differentiate their behaviour to pupils because of their gender, paying more attention and giving more freedom to boys. Boys and girls also get different communication from handbooks, songs, advertisements, TV programmes, movies. Children construct their representations of femininity and masculinity based on those messages and undertake those socially imposed roles. In peer groups they behave in accordance with social meanings of being a boy or a girl. At the time of very strong peer influence they usually interact in a stereotypical way. Concluding, boys and girls differ from each other, not because they are born like this, but because they are shaped this way by society. If the socialisation process is "successful" in the meaning of compliance with social expectations, adult women and men represent conventional types of masculinity or femininity. Otherwise they can get the label of social deviant (Meighan, 1993, pp. 323-330).

According to L. Kohlberg, because of existing social gender hierarchy, girls recognize "greater prestige of the adult man role" (Kohlberg, 1976). This weakens their positive evaluation of their own gender and results in women's lower self-esteem (Chylewska- Barakat, 2002, p. 57). It also works like 
a self-fulfilling prophecy and women's status becomes perceived as lower also by men. In an unconscious and unmeant way all internalised stereotypical beliefs of parents influence children's social representations of gender (Budrowska, 2000, p. 118).

The next level of learning gender takes place at school. Such factors as peers, teachers, handbooks, curriculum, teaching methods and language used at school play their roles. Personality and predispositions of the teacher are crucial to raising children in a school environment. The teachers have close, daily contact with the pupils and thus they influence children's opinions, beliefs and interests (Brannon, 2002, pp. 364-370). The teaching profession is feminized and thus is not highly esteemed (Reszke, 1991, p. 66). Unfortunately some research show that female teachers are often conservative and think in accordance with social prejudices concerning women (Kopciewicz, 2011).

Gender divisions emerge within school subjects. For example maths and science are perceived as subjects for boys, on the other hand humanities and arts are usually assigned to girls. No matter which gender this belief is connected to, it strongly polarizes the field of educational opportunities for girls and boys. Teachers' bias also affects children's activities. Boys are expected to be more active than girls and girls should be quiet and passive. It is more acceptable for boys to be naughty rather than for girls. The same expectations are included in contents of books. Detailed analysis of contemporary handbooks shows that mainly women are presented in family roles. They are caring mothers and they are responsible for house chores. If they are shown at work, usually those are traditional female professions like nurse, secretary, teacher. Men are connected with typical male work demanding physical strength or they occupy very high positions. At home they are breadwinners. Even if reality looks different, kids are bombarded by images of the traditional family which seems to be the only "normal" model (Chmura-Rutkowska, Duda, Mazurek, Sołtysiak-Łuczak, 2016).

Handbooks, showing a schematic, black and white world, which does not fit into differentiated, multicoloured reality, bring dissonance in the cognitive experience of students. This is contrary to the tasks they formally have toperform which is explaining the intricacies of the world, and in particular its social aspects.

Last but not least is mass media, which promotes some kinds of behaviour. These role models become the norm and the canon in a very short time. There are two dominant images of women in TV programmes and magazines - first is ideal housewife and the second is the sexpot with an ideal body. The man should be macho or professional. Only sometimes he is shown as a thoughtful father (Mizielińska, 1997, p. 238).

Already very small children get from TV programmes and commercials clear messages - girls identify themselves with the type of princess, who is beautiful, delicate and awaiting her prince charming, whereas the superheroes are models for boys- tough, strong, fighting with evil and with their 
own weaknesses, quite brutal. This leads to creation of opposite expectations - boys want to see mainly sexpots in their girlfriends, then adult men want to have perfect housewives. And they are far from being a romantic, ready to sacrifice everything for love princes from girls' dreams. It is the main reason for disappointments in relationships.

In Poland public discourse is nowadays dominated by catholic church doctrine, which promotes traditional roles and a conservative model of the family, and highly affects social representations of relationships and women's experiences. It also gets into people's minds by media messages. By that means subjective understandings and feelings are constructed by mass media.

\section{METHOD}

Thematic analysis of focus group interviews has been used to examine social representations of femininity, masculinity and relationships. It is only a small part of a larger research "Women in intimate relationships. Empirical and critical study". The above mentioned interviews were conducted with four groups of women. Three of them were of different educational background and the last one consisted of women living in lesbian relationships. The study design included younger, middle-aged and older women who had a long-term partner at the time of the interview (at least five years of relationship). Interviewees were recruited through the centre of continuing education in a medium-sized town - with about 21000 inhabitants. The centre sought volunteers for a research project concerning intimate relationships. Interviews lasted approximately 1-1,5 hour and were recorded and transcribed. Interviewees were assured of confidentiality. A coding framework was devised to identify the key themes that characterized the women's interviews and guide the thematic analysis of the textual corpus. It was developed on the basis of reading all of the transcripts.

Focus group interviews are popular in social representations study, because of the co-construction of meanings which becomes possible in the context that the focus group constitutes (Wibeck 2001, p. 287).

\section{GENDER(ED) SOCIAL REPRESENTATIONS - FINDINGS}

The main questions which reinforced the research were:

- What representations of intimate relationships and gender roles are present in women's statements?

- Which of them are ingroup and which are outgroup representations?

- Which of them do women identify with?

Four leading themes were present in the analysed material. They represent the elements constituting the relationship between life partners. 
Theme 1: Social representation of (ideal) woman

In this part of the article the social representation of the ideal woman is analysed. Of course the term "ideal" corresponds to society's point of view. Social expectations reflect in women's verbal acts and interactions during conducted FGIs. The first iterative pattern in women's representations is the idealized image of female body. One of the respondents says about this:

“...Ladies, who (...) do not have any flaws. Though they never go to toilet, they don't use it, and men worship them more than life! (...) It is just a flawless woman and so on..."[F1_D]

Social expectations include very restrictive standards for the look of a female's body. Women should be flawless, without any blemishes or wrinkles. They are even not supposed to have physiological needs. Only such an ideal woman can be worshiped by males. So she just has to take care of her body to be worth men's attention. Another respondent says:

"Because you know that our bodies every year... We get older, of course! Every year the body changes! And it will be changing, you have no strength. We can use botox, some facelifts. But that's nothing, you can improve it only for a moment".[F3_C]

She talks about the efforts that women have to make to look the right way. Being older is seen as a bad thing. And at the same time she indicates that achieving such ideal is impossible. It has to be frustrating for most of women.

The second pattern is household chores and parenting. Childbearing determines the activities that women can undertake:

“...Man goes out to work, a woman gives birth to a child here..."[F4_E]

Women say that all the house chores are ascribed to them, but they would like to get rid of this order. They would like to see this as the domain of the past, but it is still the dominant model of the family. They indicate that their partners also should work at home, sharing the duties:

“Yes! Cleaning up, washing, ironing. That can't be assigned only to women, because it was like that at the time of our grandmothers, that is our role too, but we would like also...? Our partners to be involved". [F2_C]

Meanwhile their partners are rather willing to force them to fit into their mothers' roles. Sometimes it happens by shaming. One respondent mentions that her partner usually says:

"»My mom does it like that...", and such discharging, that the house is my duty now..."[F2_C]

This way the partner says: "My mother does it better. You should be like her, because this is the real woman". In such situation anger and helplessness 
comes first, but then women often become submissive. The price is living with a sense of failure and defeat. Sometimes men link to the past in a different way:

"So woman creates home and sometimes husband says: »But ...« he says, "...already in the Middle Ages it was like that - a woman created home and a man was hunting «". [F2_C]

Men say that this allocation of roles has been around for ages. They do not admit that reality changes, so the roles should also be elastic. It is quite understandable, because such an arrangement of social world is convenient for them. Female respondents do not perceive this as fair enough. They say:

"More responsibility falls on a woman".[F2_E]

or

"A woman works all the time - at work and at home!"[F2_B]

This is the evidence of an overload of duties. There are a lot of things to do:

"And a mom needs to carry a child to kindergarten or to school during her worktime, she has to carry it to her husband, she must buy medicines, and deliver them home, and she must arrange daily care, is it not like that? (...) She has to tutor children's homework, take care of everything...". [F2_E]

Women point out that their partners do not help them in daily routines, especially connected to childrearing. Moreover they assign themselves the fault for this state:

"It is our - women's fault that we can handle it all everything! This is too much! We do several things at once!" [F2_E]

Again and again they emphasize their multitasking:

"Why can't we leave the table, leave the plate or only put in the dishwasher (...) and go to another room".[F2_D]

"Because you will have to wash everything next day! (laugh)" [F2_C]

Their partners do not feel obliged to do anything at home. And they do not feel responsible for daily needs of the household.

"Why do we need to know, for example, if something is in the fridge or maybe something is missing? Is it better? Whether buy something or not - and it happens everyday!?" [F2_D]

Another element of the social representation of the ideal woman is the tendency to sacrifice. Especially when women have children, they feel that they have to leave behind their hobbies and pleasure. 
"But now as I became a mother, of two children, yes. »Why do you go to these poetry meetings? Why do you need it? Isn't it a waste of time? Wouldn't it be better to sit, tidy the house and not complain, that you have to clean up till 1a.m.«".[F2_C]

They are supposed only to clean up, cook, do the laundry. Those are demands of their partners. Homosexual respondents claim that this is domain of heterosexual relationships. They acknowledge and criticise this talking about relationships of their heterosexual colleagues:

"They do so, that because of their stupidity just... so to speak... they squander their... needs, and the guy is the main breadwinner for the whole family".[F4_B]

They recognize this situation as social injustice, whereas heterosexual respondents also see this, feel unhappy, but someway accept this as a status quo.

The next pattern is women's social status. Respondents indicate that woman in Polish society exists only through being represented by a man. A good example is taking husband's surname when woman gets married:

"Girls who are around me, I have the impression that they had thought, they would become themselves thanks to a man. The mere fact that they take his surname. Well, for me it is the first step in getting rid of yourself, a symbolic step. What kind of idea is it to get rid of your own surname? I don't know. This is so dominant to me, so violating personal borders, such a disesteem".[F4_B]

Only some of them feel that this is not right, because it is an act of symbolic violence. The majority of women in the Polish cultural context are proud of this tradition. Moreover, women assume the passive position in society and do not want to be a part of civil society:

"Of course I am all for the idea of parity. Why? Because women in our country are better educated and statistically there is no reason for not acknowledging the equality, but of course we still live in the Matrix, in this standard, and women do not stand... in elections, they do not want this". [F4_B]

They still believe that public sphere is reserved for men. Women's roles are more connected to family and home. Only very few woman raised this issue during FGIs.

\section{Theme 2: Social representation of the (ideal) man}

The second social representation is connected to the image of ideal man/ partner. Those expectations concern mainly his character. Most respondents wish their partners were similar to their fathers:

"About the partner? As my dad is. YES! As Dad! Calm, muted...". [F1_E] 
Some of them see the movie stars as the model types of potential partners:

"Perhaps you will be laughing at me, because when I was a teenager, I was deadly in love with Van Damm and I was always saying (laugh), that when I grow up, I'll marry him (laugh). I... I really liked it, that he could fight, he was able to defend those women. Athletic, strong, dealing with everything, and for women and children he was sensitive, caring, able to save them, and so on. But unfortunately... a few years later, I learned that in his real relationships, not in the movies, he beats his female partners". [F2_C]

They are partially aware that this image is only created for the needs of the media, but still construct their representation of man on the basis of media figures:

"One used to think about some kind of a model. Yes. For sure". [F3_B]

"Superman? (laughs)" [F3_A]

"No, Superman - no, no, no Superman. But perhaps the man who somehow understands you. Because I think that we want this above all, right?" [F3_B]

During the FGIs women were talking about superheroes and macho-type actors as ideal partners, but at the same time they were covering the real message with laugh. It seems they wish to have such superheroes-partners at home, but simultaneously they know that this is impossible, so they are supposed to choose something more realistic. Moreover the partner should be romantic:

"But, I'll tell you that women expect it. Just as I get, for example, bouquets on our wedding anniversary. And one there was my mother. She said that she misses it, that she never got something like this from her husband". [F1_E]

The vision of macho-romantic lover seems to be the dominant representation of a man who fits into women's expectations.

The next emphasized feature of a social representation of a man is his social status. And again women want their partners to be the heroes of Fairly Tales:

"Prince Charming (laugh)".[F3_B]

“(...) Just as you said, one dreamed about... O, God!... the prince from a fairy tale on a white steed, which will come someday ... and then it changes over time".[F3_C]

And again they laugh about it and say that it is not a very realistic image. But there is no doubt that the ideal husband should be rich, no matter if he is a prince or a farmer: 
“And so we go by Kaszuby [a region of Poland - M.G.]... and I said that I'1l have a rich husband. And if I won't find any rich husband, well, I'll take some peasant, who will be driving a tractor on the field, and I'll be dealing with house chores".[F4_E]

When the partner is rich enough to keep a family, the woman is ready to stay at home and fulfil the traditional role of housewife. It is quite surprising that even homosexual women used to have this kind of expectations, before they started relationships with females. It shows that social representations connected to intimate relationships, constructed in the dominant discourse, appear very early and are very strong. It is hard to resist.

The appearance of potential partner is also very important. Women imagine their ideal partners with the details:

"How should he look like? I wish he was taller than me, for example. I wish he had black hair, black eyes ... I do not know... he played the guitar...". [F1_F]

Again the tallness is representation of strength and the guitar represents the romanticism. The most important thing is the size of the body. Man should be taller and bigger than woman:

"Calmly. I always thought that he must be tall. I don't like any runts, shorter than one meter. I am rather short myself... and TALL GUY is the one you can lean against". [F1_E]

Women also admit that the appearance of men is not important to them. Females pay a lot of attention to external determinants of choosing a partner. Personality traits appear afterwards:

"It is well known that she has her needs, external reasons, and she matures with age to notice the inside, not only the outside appearance. She becomes interested in inside factors and values that this particular man represents". [F3_E]

It is quite the opposite to what society used to think about women. Woman pay attention to men's bodies, but personality factors in women's expectations seem to replace the physical ones over time, because it seems to be very immature to look only for the right body type.

Clearly above images come from media system. Even men perceive them as setting too high expectations:

"And my husband always says: »you got it, silly hags, you watch too much of these romances... and then you demand too much. You expect too much from us. And this is a nonsense made up for the purposes of... Oh, I'll find such and such a guy, right «". [F2_C]

They are aware of female's expectations and feel unsafe with it. They try to call into question media images and re-present them as nonsense. 


\section{Theme 3: Social representation of (ideal) intimate relationship}

The third theme are relations in a relationship, especially the issue of dominance and power. FGI respondents indicate that they would like to have relationships like their parents marriages:

"I wish I had such a relationship as my parents. Always I look at it, and I'd love to have such relations".[F1_D]

The family home is both a positive and negative model of behaviour in a relationship. When women evaluate their parents' relationships as happy, they would like to have similar one in their lives. But sometimes the family home is also a source of negative behaviour patterns:

"To guide him more or to be guided by him, it is just such a pattern taken from family home". [F1_C]

The woman usually undertakes the role which is similar to the role of her mother, which is not necessarily the best choice in their own relationships:

"I also now wonder how our parents' relations are the first model for us and of course I was building my vision of my relationships on the basis of this internalized parenting of my dad and my mum. Internalized means that it was deep inside me. I come from home where the mother is an empress. I mean... very strong woman, the manager... the doctor. Extremely dominant, and my father, who deals with minor issues... (laughs)". [F4_B]

People mindlessly transfer the models from their family homes, behave as if they were their own parents and it usually doesn't fit to the new reality of their own family. Sometimes it is completely unacceptable and unsuitable for their partners:

“Well, I'm not surprised that some of the relationships, for example, enter into such a domination and dependency, submission, because people transfer their parents' to their own lives, for example, where the father is dominant, or the mother is dominant, but then it doesn't work, right? It turns out that we don't fit into the statistical standard, into this normality, and that (...) we need to create anew a definition, which we do not know from our family home". [F4_E]

Both partners try to push their own division of responsibilities and roles, which is also taken from the family home. If they had different models, they can feel disappointed. Usually women are supposed to take care of the house, even if they work. In conservative family doing chores is not a masculine task. Women feel pressed into the role, which they do not want. Moreover, they are congested by a lot of work:

"Well, I say - everything changes. Although I say that he was a difficulty... in my life. Because he had a model of the family, where mum does everything. And his mother was doing everything for him. So he had no such patterns".[F1_C] 
In such situations it is easy to perceive the partner as the life obstacle. This unfair division of responsibilities results from the gendered process of socialization. It starts very early:

“... As I go to 5-10-15 or Child's World" [stores with children's clothes and toys - M.G.] and I see For boys - and super cool stuff. For girls - and when I see, well, these things for a girl, well, I'm terrified". [F4_B]

"Pink Princess". [other respondent, unidentified]

"Everything pink, but also, among other things, for example - cleaning sets. Well, I've seen this earlier, but it happens now, in the twenty-first century and we still have cleaning sets for girls (...) And the mother, who maybe do not think too much about the world, comes at the department, because she has a girl, she comes to the girlish department and this child... doesn't even have an occasion to play with cars, and it's so sad". [F4_B]

[Comment of other interviewees: "Genderism (laugh). Here sit only genderists (laugh)"].

Women judge this preparation for traditional roles as problematic. At the same time they know that such non-traditional viewpoint is negatively perceived in Polish society. This is expressed by the pejorative phrases: "genderism" and "genderists", which are understandable only in Polish cultural context. Those are hateful expressions used by representatives of catholic communities towards people who support a leftist point of view, who do not want the traditional gender roles, are against abortion ban, support in-vitro fertilization and homosexual relationships.

Another characteristic of ideal relationship is its everlasting continuance. Divorce is inadmissible, because of catholic tradition:

“This is from my family - in my family haven't been any divorces. No one has lived in separation. No one ever since! For generations!" [F1_E]

Social representation is based on the conviction that marriage is one for life and eternal. Some respondents see this tradition as very restrictive. They also see the risks connected to such beliefs, for example harmful violent relationships, which last for years only through women's sacrifice. Those victims cannot free themselves from the oppressors because of this tradition and social convictions.

Even the ways of spending free time together in a relationship come from the family of origin:

"Listen, moreover it was like that. My mom with my dad maybe had kept in touch with few acquaintances in a village, when they had been younger and we had been smaller, because there had been the three of us at home. But later it they didn't. By themselves. And I noticed that me and my husband are the same. We do not go anywhere".[F2_B] 
Those patterns are very strong and deeply internalized. Reproduction of roles and models is not conscious on a daily basis. Only during the interviews such processes became acknowledged and verbalized. Sometimes it was a surprise even to the respondents themselves.

\section{Theme 4: Practices in the real intimate relationships}

Last, but not least, there is also a motive of control in a relationship. Whereas the previous theme was connected to symbolic power and violence, this one is connected to the direct domestic violence. According to respondents, mainly three areas of women's lives are restricted by partners: ways of spending their time, the political or social involvement and spending money.

Partners often want to know how, where and with who women spend their time. It results in a sense of entrapment:

“In my previous relationship, I (...) I was locked in a cage. I was only for my husband, only on his call, and absolutely only for him".[F3_B]

Some women are incapacitated by their partners even when it comes to political and social involvement:

"Now we collect signatures, because we have our candidate to the Europarliament (...) Three times during collecting signatures on the street has happened to us, that the girl said she must ask her boyfriend or husband, if she could sign the list". [F4_D]

They act as if they were unable to decide by themselves. A very serious problem is also economic control:

"In Gdansk Main Station I've took recently a step-by-step picture... a shoe store with the advertisement: «Your hubby called us and said, you can buy what you want! « (laughs). And in such moments, when I see such things, I sometimes think: »How wonderful that I'm a lesbian «. I really feel sorry for these women, who have to wait for permission from their men to buy some shoes". [F4_D]

According to declarations of respondents, homosexual relationships are free from such constrains. Despite working and earning money, women cannot buy what they want. The presence of this theme even in commercials shows that this is very common in relationships:

"And my colleagues ran from work 15 minutes before the end time, to go shopping, buy another pair of shoes... and then they really keep these shoes in a box for two weeks hidden in the closet, so that he would not see". [F4_D]

During FGIs this issue triggered great emotions. Women feel inequity inscribed into heterosexual relationships, where the patriarchy takes its toll. Discursively transmitted symbolic social violence is reflected by everyday practices in intimate relationships. Controlling and dominant behaviour of 
male partners is so common, that they seem to be "natural" and become invisible to the victims. To this situation perfectly fits the metaphor used at the end of 90's by Henryk Domański in the title of the series of his books - "a happy slave". He called this way females' position in Polish society. Today women's situation in the public sphere and the labour market is slowly changing, but it seems that they are still "slaves" in their own homes.

\section{CONCLUSIONS}

Social representations come from the public discourse, which is the result of intermingling political, science and media discourses. Social representations are the basis of women's expectations towards intimate relationships. Representations in this sense are encoded in the environment and culture (Norman, 1993), they stem from the social context, so they are not necessarily connected to the real needs and desires of women .Behaviour in relationships is constituted by representations of female and male roles, which affect the representations of intimate relationships.

As D. Jodelet argues, a representation can be "used for acting in the world and on others" (Moscovici, 2000, p. 12), as well as for re-acting, rejecting or re-forming a presentation of the world that conflicts with one's stake, position and identity (Howarth, 2006, p. 6). As the result of socialisation in woman's mind appears one of the two types of representation - a real representation (compatible with future experience) or a false representation (unrealistic expectations based on social "myths”). On this basis people make their choices of partners. Those representations also determine their expectations, which mean the effect of actions and behaviour in the relationship. Undertaking actions women expect some effects consistent with the representation. An actual outcome can be in line with expectations or not. The effect in line with expectations results in pleasure, gives happiness. The effect inconsistent with expectations instead results in a cognitive dissonance and a lot of unpleasant feelings. This experienced dissonance provokes modifying wrong representations and thereby reduce the dissonance. If the process of modifying representations was determined only by the experience, it is likely it would lead to establishing correct representations. But in this process external variables also take part - social myths and mediated experience information which comes from other people and from media, that is, from the number of discourses of intimate relationships co-existing in the public sphere, full of gender bias. These types of messages cause distortion in the process of modifying representations and lead to formation of further false representations, thereby to further unmet expectations and to other mismatched relationships. Social representations opposite to the real needs make women's lives unhappy.

Concluding, social representations of intimate relationships shared among women are rooted in public discourse and shaped within the process of infor- 
mal learning. Bias connected to the roles of man and woman become a part of social representations of intimate relationships and influence practices of "being-in-relationship". Those practices often do not fit life situations, which is evidenced in FGI analysis by the contrast between social representations of relationships and stories about experience and practices in real relationships.

\section{REFERENCES}

[1] Brannon, L. (2002). Psychologia rodzaju. Kobiety i mężczyźni: podobni czy różni [Psychology of Gender. Women and Men: Similar or Different?]. Gdańsk: Gdańskie Wydawnictwo Psychologiczne.

[2] Budrowska, B. (2000). Macierzyństwo jako punkt zwrotny w życiu kobiety [Maternity as the Turning Point in Female's Life]. Wrocław: Wydawnictwo Funna.

[3] Castoria, J. A. (2010). The Ontogenesis of Social Representations: A Dialectic Perspective. Papers on Social Representations, 19, 18.1-18.19.

[4] Chmura-Rutkowska, I., Duda, M., Mazurek, M., Sołtysiak-Łuczak, A. (Eds.) (2016). Gender w podrecznikach. Projekt badawczy. Raport [Gender in School Handbooks. Research Project. Report]. Warszawa: Fundacja Feminoteka.

[5] Chylewska-Barakat, L. (2002). Agresja a psychologiczne aspekty ptci w perspektywie rozwojowej [Aggression and Psychological Aspects of Gender in Developmental Perspective]. In: A. Hulewska, A. Jasielska, M. Ziarko (Eds.), Interdyscyplinarne studia nad ptcia. Od polaryzacji ptciowej ku depolaryzacji rodzajowej [Interdisciplinary Studies on Gender. From Sex Polarisation to Gender Depolarisation] (pp. 53-57). Poznań: Wydawnictwo Fundacji Humaniora.

[6] Crompton, R., Lyonette, C. (2005). The new gender essentialism - domestic and family 'choices' and their relation to attitudes. The British Journal of Sociology, 56, 601-620.

[7] Czapiński, J., Panek, T. (Eds.) (2015). Diagnoza społeczna 2015. Warunki i jakość życia Polaków. Raport [Social Diagnosis 2015. Conditions and the Life Quality of the Poles]. Warszawa: Rada Monitoringu Społecznego.

[8] Dakowicz, A. (2000). Płeć psychologiczna a samoaktualizacja [Psychological Gender and Self-realisation]. Białystok: Trans Humana.

[9] Duveen G. (2000). The Power of Ideas. Introduction. In: S. Moscovici (Ed.), Social Representations. Explorations in Social Psychology (pp. 1-17). Cambridge: Polity Press.

[10] Duveen G., Lloyd B. (Eds.) (1990). Social Representations and The Development of Knowledge,. Cambridge: Cambridge University Press.

[11] Duveen G., Schields M. (1985). Children's Ideas about Work, Wages and Social Rank. Cahiers de Psychologie Cognitive, 5, 411-412.

[12] Duveen, G. (1993). The Development Of Social Representations Of Gender. Papers on Social Representations - Textes sur les Représentations Sociales, 2 (3), 1-7.

[13] Foster J. (2003). Representational Projects and Interacting Forms of Knowledge. Journal for the Theory of Social Behaviour, 33(3), 231-244.

[14] Giddens,A. (2004). Socjologia [Sociology]. Warszawa: Wydawnictwo Naukowe PWN.

[15] Glaveanu, V. P. (2009). What Differences Make a Difference? A Discussion of Hegemony, Resistance and Representation. Papers on Social Representations, 18, 2.1-2.22.

[16] Greenwood J. D. (1991). Relations and Representations. An Introduction to the Philosophy of Social Psychological Science. London: Routledge.

[17] Grochalska, M. (2006). Życie rodzinne pracujacych zawodowo kobiet $i$ ich relacje $z$ bezrobotnymi mężami [Family Life of Working Women and Their Relationships with Unemployed Husbands]. In: J. Ostrouch, J. (Ed.), Przywiazanie i przekraczanie. Płeć w studiach empirycznych [Attachment and Transcending. Gender in Empirical Studies] (pp.115-137). Olsztyn: Wydawnictwo UWM.

[18] Höijer, B. (2011). Social Representations Theory. A New Theory for Media Research. Nordicom Review, 32/2, 3-16.

[19] Howarth, C. (2002). Using the Theory of Social Representations to Explore Difference in the Research Relationship. Qualitative Research, 2 (1), 21-34. 
[20] Howarth, C. (2006). A Social Representation is Not a Quiet Thing: Exploring the Critical Potential of Social Representations Theory. British Journal of Social Psychology, 45 (1), 65-86.

[21] Jodelet D. (2008). Social Representations: The Beautiful Invention. Journal for the Theory of Social Behaviour, 38:4, 411-430.

[22] Jodelet, D. (1991). Madness and Social Representations. Hemel Hempstead: Harvester Wheatsheaf.

[23] Jodelet, D. (1998). Ciato, osoba i inni [Body, the Person and Others]. In: S. Moscovici (Ed.), Psychologia społeczna w relacji Ja-Inni [Social Psychology in Relation Me-Others]. Warszwa: WSiP.

[24] Jovchelovitch S. (2007). Knowledge in Context. Representation, Cummunity and Culture, London: Routledge.

[25] Kaschak,E. (2001). Nowa psychologia kobiety. Podejście feministyczne [New Psychology of Women. Feminist Approach]. Gdańsk: Gdańskie Wydawnictwo Psychologiczne.

[26] Kohlberg, L. (1976). Moral Stages and Moralization: The Cognitive-Developmental Approach. In: T. Lickona (Ed.), Moral Development and Behavior: Theory, Research, and Social Issues (pp. 31-53). New York: Holt, Rinehart and Winston,

[27] Kopciewicz, L. (2011). Nauczycielskie ponizanie. Szkolna przemoc wobec dziewczat [Teacher's humiliation. School Violence towards Girls]. Warszawa: Difin.

[28] Linton, A. Ch. (2015). To Includeor Not to Include: Teachers' Social Representations of Inclusion of Students with Asperger Syndrome. Linköping Studies in Arts and Science, 656, Studies from the Swedish Institute for Disability Research No.75, Linköping University, Department of Behavioural Sciences and Learning, Linköping.

[29] Lisowski, A. (1996). Badanie potrzeb spotecznych [Exploring the Social Needs]. Warszawa: Interart.

[30] Markova, I. (2010). Gerard Duveen on the Epistemology of Social Representations. Papers on Social Representations, 19, 4.1-4.9.

[31] Meighan,R. (1993). Socjologia edukacji [Sociology of Education]. Toruń: Wydawnictwo UMK.

[32] Mizielińska,J. (1997). Matki, żony, kochanki, czyli tak nas widza. Kobieta jako podmiot i przedmiot reklamy [Mothers, Wifes, Lovers, or So They See Us. Woman as the Subject nad Object of Advertisement]. In: J. Brach - Czaina (Ed.), Od kobiety do mężczyzny i z powrotem. Rozważania o ptci w kulturze [From Woman to Man and Back. Reflections on Gender in Culture] (pp. 226246). Białystok: Trans Humana.

[33] Moscovici S. (1993). The Invention of Society: Psychological Explanations for Social Phenomena, Cambridge: Polity Press.

[34] Moscovici S. (1998). Elementarne formy altruizmu [Elementary forms of altruism]. In: S. Moscovici (Ed.), Psychologia społeczna w relacji Ja-Inni [Social Psychology in Relation Me-Others]. Warszawa: WSiP.

[35] Moscovici S. (2010). Let Us Not Forget to Think, Nor the Thinkers! Papers on Social Representations, 19, 1.1-2.4.

[36] Moscovici, S. (2000). Social Representations: Explorations in Social Psychology. Cambridge: Polity Press.

[37] Norman, D. A. (1993). Cognition in the Head and in the World: An Introduction to the Special Issue on Situated Action. Cognitive Science, 17, 1-6.

[38] Nowak-Dziemianowicz, M. (2002). Doświadczenia rodzinne w narracjach. Interpretacje sensów $i$ znaczeń [Family Experiences in Narratives. Interpretations of Senses and Meanings]. Wrocław: Wydawnictwo Naukowe DSWE.

[39] Philogene G., Deaux K. (Eds.) (2001). The Representation of the Social: Bridging Theoretical Perspectives. New York: Basil Blackwell.

[40] Purkhardt C. (2015). Transforming Social Representations: A Social Psychology of Common Sense and Science. New York: Routledge.

[41] Renzetti, C. M., Curran, D. J. (2005). Kobiety, mężczyźni i społeczeństwo [Women, Men and Society]. Warszawa: Wydawnictwo Naukowe PWN.

[42] Reszke, I. (1991). Nierówności płci w teoriach. Teoretyczne wyjaśnienia nierówności płci w sferze pracy zawodowej [Gender Inequalities in Theories. Theoretical Explanations of Gender Inequalities in the Labour Area]. Warszawa: Res Publica Press.

[43] Thorne, B. (1993). Gender Play: Girls and Boys in School. New Brunswick-NJ: Rutgers University Press. 
[44] Turner, J. H. (1998). Socjologia. Podstawowe pojęcia i ich zastosowanie [Sociology. Basic Concepts and Their Applications]. Poznań: Zysk i S-ka.

[45] Wachelke, J. (2012). Representations and Social Knowledge: an Integrative Effort Through a Normative Structural Perspective. New Ideas in Psychology, 30, 259-269.

[46] Wagner W., Farr R., Jovchelovitch S., Lorenzi-Cioldi F., Marková I., Duveen G. and Rose D. (1999). Theory and Method of Social Representations. Asian Journal of Social Psychology, 2 (1), 95-125.

[47] Wagner, W. (1994). Fields of Research And Socio-Genesis of Social Representations: A Discusson of Criteria and Diagnostics. Social Science Information, 33/2, 199-228.

[48] Wibeck, V. (2001). Exploring Focus Groups: Analyzing Focus Group Data About Genetically Modified Food. In: K. Aijmer (Ed.), Dialogue Analysis VIII: Understanding and Misunderstanding in Dialogue (287-298). Selected Papers from the 8th IADA Conference Göteborg. 